\title{
Candidates for ALA Council
}

\section{These ACRL members need your vote.}

$T_{1}$ he following members of the Association of College and Research Libraries are either nominated or petition candidates for ALA councilor in the spring 1987 elections. Members are encouraged to vote for these candidates to increase ACRL's voice in the affairs of the American Library Association.

Robert Almony, University Libraries, University of Missouri, Columbia, Missouri.

Mary Birmingham, METRONET, St. Paul, Minnesota.

Clarence E. Chisholm, Clinch Valley College of the University of Virginia, Wise.

Marva DeLoach, Milner Library, Cataloging and Records, Illinois State University, Normal.

Catherine F. Doyle, Christopher Newport College Library, Newport News, Virginia.

Jack Forman, Mesa College Library, San Diego, California.

Elaine A. Franco, Cataloging Dept., University of Nebraska Library, Lincoln.

Salvador Guerena, University Library, Univer-

\section{LOEX survey}

For the first time in 15 years, the LOEX Clearinghouse for Library Instruction will conduct a national survey of bibliographic/library instruction activities and programs in United States academic libraries. Questionnaires are being sent out this month to any academic library that has contacted LOEX since 1972

Results of the survey will update all information in the LOEX database on library instruction. Please participate! If your academic library is not a current member, you may receive a questionnaire by contacting: Teresa Bungard, Director, LOEX Clearinghouse, Eastern Michigan University, University Library, Ypsilanti, MI 48197. sity of California, San Diego.

Sharon A. Hogan, Louisiana State University Libraries, Baton Rouge.

Norman Horrocks, Scarecrow Press, Metuchen, New Jersey.

Edward R. Johnson, Willis Library, North Texas State University, Denton, 'lexas.

William Jones, University of Illinois at Chicago.

Barbara Kile, Fondren Library, Rice University, Houston, Texas.

Robert Klassen, Library Programs, U.S. Department of Education, Washington, D.C.

James J. Kopp, Washington State University Libraries, Pullman.

Janice T. Koyama, Moffitt Undergraduate Library, University of California, Berkeley.

Nancy C. Kranich, Public and Administrative Services, New York University Libraries, New York City.

Charles J, Kratz, Hofstra University Library, Hempstend, New York.

Tze-chung Li, GSLIS, Rosary College, River Forest, Illinois.

Ron Naylor, University of Miami, Coral Gables, Florida.

G. Charles Newman, E.H. Butler Library, State University College, Buffalo, New York.

Sandra K. Peterson, Government Documents Center, Yale University, New Haven, Connecticut.

John V. Richardson Jr., GSLIS, University of California, Los Angeles.

Sharon J. Rogers, George Washington University I ibrary, Washington, D.C.

John Sheridan, Colorado College Library, Colorado Springs.

Barbara J. Smith, Pattee Library, Pennsylvania State University, University Park.

James C. Thompson, University of California, Riverside.

Robert A. Walter, Government Documents, Pittsburg State University, Pittsburg, Kansas. 


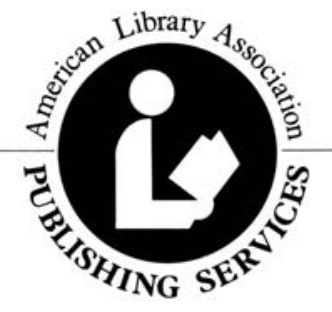

Public Access Microcomputers in Academic Libraries: The Mann Library Model at Cornell University. Howard Curtis, editor.

\$14.95pbk. 272p. 0-8389-0464-5 86-22315 March 1987

For academic librarians, university and library administrators, and personnel in university computing centers, an insightful study of the process of integrating a sophisticated publicaccess microcomputer facility into academic library programs of instruction in information literacy, online services, and collection development.

Dollars and Sense: Implications of the New Online Technology for Managing the Library. Bernard Pasqualini, editor.

\$10.00pbk. 118p. 0-8389-3338-6 February 1987

Provides both administrators and reference staff with practical perspectives on managing an online search facility and on the impact that online information resources have on library services as a whole. (Proceedings of a 1986 conference program sponsored by ALA's Reference and Adult Services Division.)

Selection of Library Materials in Applied and Interdisciplinary Fields.

Beth J. Shapiro and John Whaley, editors.

\$42.00cl. approx. 352p. 0-8389-0466-1 86-32101 June 1987

Assists both new and experienced bibliographers by examining collection development in 18 applied and interdisciplinary fields. The structure of each field is described and the pattems of scholarship, current research directions, sources of literature, and supporting bibliographic tools are identified.

How to Do Research, 2nd ed. Nick Moore.

\$20.00cl. 140p. 0-85365-787-4 ALA order code L787-4 March 1987

Gives practical advice and encouragement to the scholar or student planning original research in the social sciences, especially those conducting a research project for the first time. Each stage of a research project is described, from defining the objective of the study to disseminating the results.

\section{American Library Association Publishing Services}

50 East Huron Street - Chicago, Illinois 60611 


\section{6-MONTH TRIAL SUBSCRIPTION!}

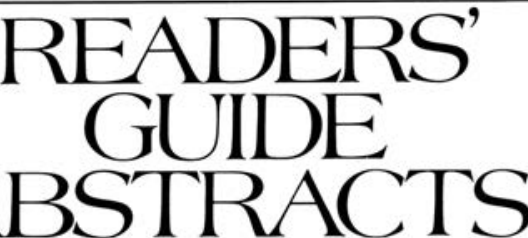

\section{ABSTRACTS AND INDEXING ON TYPESET FICHE}

The Wilson Company now offers high-quality abstracts for its best-known index,

Readers' Guide to Periodical Literature. Combining abstracts with indexing on easy-to-read typeset microfiche, Readers' Guide Abstracts makes research faster, easier, and more efficient than ever before.

\section{QUALITY INFORMATION} IN A QUALITY PACKAGE High-Quality Abstracts Well-written, accurate abstracts accompany the entry for each article indexed.

Readers' Guide Indexing The full cross-reference structure and indexing for each of the more than 180 periodicals covered in Readers' Guide are offered in Readers' Guide Abstracts.

\section{Readability}

Readers' Guide Abstracts retains the format and typography of Readers' Guide, using bold face and italic type to distinguish the components of each entry.

Easy to Display and Store

Each cumulation is delivered already filed in a durable display kit. Currency Readers' Guide Abstracts is updated and cumulated eight times each year.

\section{Retrospective Coverage}

Indexing and abstracting coverage beginning January 1986 is cumulated with recent material in every issue of Volume II (1987).

\section{MICROFICHE READER AND READER/PRINTER AVAILABLE}

As a special offer to Readers' Guide Abstracts subscribers, Wilson is offering high-quality Bell + Howell microfiche readers and reader printers at reduced rates.

The Micro Design 895 (48x) microfiche reader is available to subscribers at $\$ 188$, non-subscribers pay $\$ 288$.

The Micro Copy 10 (48x), reader/ printer is available to subscribers at $\$ 399$; non-subscribers pay $\$ 499$.

\section{SPECIAL OFFER!}

6-Month Trial Subscription

With your no-risk 6-month trial subscription to Readers' Guide Abstracts, you will not be invoiced until you enter your order for an annual subscripti in. If after your 6-month examination period you are not satisfied, we will arrange for the return of the fiche you have received-there will be no financial obligation.

Your subscription to Volume II (1987) of Readers' Guide Abstracts brings you eight cumulations issued approximately every six weeks, beginning May 1987. Each cumulation of Volume II contains retrospective coverage beginning in January 1986. An annual subscription is priced at $\$ 675$ U.S. and Canada, $\$ 750$ other countries.

To Order Call Toll-Free 1-800-367-6770

In New York State, call 1-800-462-6060;

in Canada, call collect 212-588-8400.

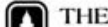

H.W. WIL SON COMPANY 950 University Avenue Bronx, New York 10452 (212) $588-8400$ 